\title{
"Júri Simulado" como estratégia de reflexão de um desastre ambiental, no ensino médico de uma Instituição Pública de Ensino Superior do Leste de Minas Gerais
}

Wanessa Françoise da Silva Aquino do Carmo, Eulilian Dias de Freitas, Waneska Alexandra Alves, Lélia Cápua Nunes

\begin{abstract}
Resumo
Em novembro de 2015, Governador Valadares-MG sofreu o impacto do maior desastre ambiental ocorrido no Brasil. Os rejeitos de minério do rompimento das barragens em Mariana-MG atingiram e devastaram o Rio Doce, principal fonte de água potável do município, gerando insegurança alimentar e prejuízos social, econômico e à saúde. $\mathrm{O}$ fato motivou a realização de uma estratégia de júri simulado, com temática “Atividades da Mineradora em Mariana: embargar ou liberar?", na disciplina Saúde Ambiental, do curso de medicina de uma instituição pública de ensino superior de Governador Valadares-MG. O júri simulado é a reprodução de um julgamento, no qual são apresentados argumentos de defesa e de acusação para análise de um problema. Debater sobre o desastre ambiental do rompimento das barragens de minério sob a ótica da saúde coletiva. Os estudantes foram divididos em três grupos: acusação, defesa e jurados. O juiz do processo foi um docente. Os grupos tiveram trinta dias para preparar o processo, contendo: descrição do caso, argumentos de defesa/acusação, responsabilidades, consequências em curto, médio e longo prazos e possíveis cenários futuros. No júri, a defesa e a acusação apresentaram o processo, com discussão dos argumentos. Em seguida, os jurados fizeram perguntas para esclarecimento de termos e detalhamento das questões abordadas. O júri reuniu-se para preparar o veredito e a sentença, que consistia da descrição do resultado da votação, ponderação e recomendações. O julgamento teve início pela acusação, com argumento de que a Mineradora infringiu a legislação ambiental, negligenciou o risco de rompimento das barragens, retirou da população ribeirinha o direito de conviver com um meio ambiente preservado e não arcou com o prejuízo social e econômico gerado. A defesa alegou que as barragens eram monitoradas e que embora não houvesse o sistema de alarme, a empresa conseguiu avisar a população atingida e está prestando assistência. $\mathrm{O}$ veredito constou que a Mineradora é culpada pela negligência quanto à segurança das barragens e falha na prevenção e comunicação de acidentes, porém a mesma deve retomar suas atividades, por ser importante fonte de empregos e arrecadação para o município de Mariana. A atividade foi dinâmica, estimulou a aquisição de competências e habilidades de liderança, gestão do tempo e escuta qualificada e estimulou a postura ativa e crítica dos estudantes. Além disso, demonstrou a complexidade da questão ambiental e suscitou a reflexão sobre o impacto de fatores distais, como políticas e legislação ambiental, na saúde da população.
\end{abstract}

Descritores: Instituições Acadêmicas; Educação em Saúde; Estudantes de Medicina. 